\title{
Occurrence of extended-spectrum cephalosporinase producing Escherichia coli in kuroiler birds
}

\author{
Pratik Ghosh ${ }^{1}$, Achintya Mahanti ${ }^{1}$, Indranil Samanta ${ }^{1 *}$, \\ Siddhartha N. Joardar ${ }^{1}$, Kunal Batabyal ${ }^{1}$, Samir Dey ${ }^{1}$, Subhash Taraphder ${ }^{2}$, \\ and Devi P. Isore ${ }^{1}$ \\ ${ }^{I}$ Department of Veterinary Microbiology, West Bengal University of Animal and Fishery Sciences, Sarani, \\ Belgachia, Kolkata, West Bengal, India \\ ${ }^{2}$ Department of Animal Genetics and Breeding, West Bengal University of Animal and Fishery Sciences, \\ Sarani, Belgachia, Kolkata, West Bengal, India
}

GHOSH, P., A. MAHANTI, I. SAMANTA; S. N. JOARDAR; K. BATABYAL, S. DEY, S. TARAPHDER, D. P. ISORE: Occurrence of extended-spectrum cephalosporinase producing Escherichia coli in kuroiler birds. Vet. arhiv 87, 745757, 2017.

\section{ABSTRACT}

The present study was undertaken to detect the incidence of extended-spectrum-cephalosporinase gene possessing-Escherichia coli, its co-resistance pattern against other antimicrobials, and the clonal relationship of the isolates in healthy kuroiler birds. A total of 80 cloacal swabs from kuroilers were collected randomly from West Bengal, India. The use of costly antimicrobials (cephalosporins) was not practiced by farmers. Escherichia coli was isolated and identified by standard biochemical tests and 16SrRNA-PCR. All the E. coli isolates, including controls, were subjected to PCR for detection of bla $a_{C T X-M}, b l a_{T E M,}, b l a_{S H V}$ and $b l a_{C M Y-2}$ genes. By comparing the RAPD-banding pattern, the phylogenetic relationship among the isolates was established. All the isolates were tested for phenotypical resistance against other antibiotics. In total, 60 isolates were identified as E. coli from the kuroilers studied $(\mathrm{n}=80)$. Among them, $12(20 \%)$ isolates possessed one of the studied extended-spectrum cephalosporinase genes. Among the studied genes, $b l a_{T E M}$ and $b l a_{S H V}$ were detected in 6 $(10 \%)$ and $12(20 \%) E$. coli isolates, respectively. None of the E. coli isolates possessed bla $a_{C T X-M}$ and $b l a_{C M Y-2}$ In phylogenetic analysis, the strains isolated from same localities with similar genetic profile were grouped into the same cluster. Resistance of extended-spectrum cephalosporinase gene possessing $E$. coli isolates was observed most frequently against ampicillin/cloxacillin, co-trimoxazole, amoxyclav, piperacillin, ceftriaxone, and tetracycline. Kuroiler birds with no cephalosporin usage profile may act as a reservoir of extended-spectrum cephalosporinase gene possessing $E$. coli. This is the first systematic study in kuroilers, to raise the awareness of consumers regarding the possibility of transmission of antimicrobial resistant $E$. coli from them.

Key words: E. coli, extended-spectrum cephalosporinase, India, kuroiler

\footnotetext{
*Corresponding author:

Dr. Indranil Samanta, Department of Veterinary Microbiology, West Bengal University of Animal and Fishery Sciences, 37 , K.B. Sarani, Belgachia, Kolkata-700037, West Bengal, India, Phone: +91 906291 8679, E-mail: isamanta76@gmail.com
} 
P. Ghosh et al.: Extended-spectrum cephalosporinase possessing E. coli in kuroilers

\section{Introduction}

Transmission of zoonotic bacteria from animals or birds to humans is further complicated by the association of antimicrobial resistance. Among different mechanisms selected by the antimicrobial resistant Escherichia coli strains, production of cephalosporinase, such as extended-spectrum beta-lactamase (ESBL) and ampC $\beta$-lactamases, has been commonly observed over past decades (REICH et al., 2013). The presence of extended-spectrum beta-lactamase (ESBL) producing $E$. coli in humans can confer resistance to a variety of $\beta$-lactam and other antibiotics, including penicillins, $2^{\text {nd }}$, $3^{\text {rd }}$ and $4^{\text {th }}$-generation cephalosporins and monobactams (e.g. aztreonam), but usually not carbapenems or cephamycins (MARCHAIM et al., 2010). However, ampC $\beta$-lactamases provide resistance to penicillins, $2^{\text {nd }}$ and $3^{\text {rd }}$-generation cephalosporins, including $\beta$-lactam/inhibitor combinations, cefamycins (cefoxitin), but usually not to $4^{\text {th }}$-generation cephalosporins (cefepime, cefquinome) and carbapenems (EFSA PANEL ON BIOLOGICAL HAZARDS, 2011) The economic burden of antimicrobial resistance is significant, due to delayed response to treatment and prolonged stay in hospital (DE KRAKER et al., 2011). There are three classical ESBLs, i.e. TEM (except TEM-1), SHV (except SHV-1 and 2) and CTX-M (EFSA PANEL ON BIOLOGICAL HAZARDS, 2011).

Among food animals that act as reservoirs of ESBL-producing E. coli, broilers are considered to be the most potent reservoir (PACHOLEWICZ et al., 2015). Almost all the ESBL genes are carried by mobile genetic elements of $E$. coli, and the genes can spread both clonally and horizontally among different lineages of E. coli (GHODOUSI et al., 2015). Earlier studies revealed the similarity between ESBL-producing E. coli strains isolated from humans and chicken meat, based on multilocus sequence typing, phylotyping, ESBL genes, plasmid replicons, virulence genes, amplified fragment length polymorphism and pulsed-field gel electrophoresis, which suggests the transmission and colonization possibility of bacteria or their genes in humans (KLUYTMANS et al., 2013).

The possibility for all animals and birds to act as reservoirs of extended-spectrum cephalosporinase-producing $E$. coli and the route of transmission from the reservoirs is still unexplored (EFSA PANEL ON BIOLOGICAL HAZARDS, 2011). Moreover, extendedspectrum cephalosporinase-producing $E$. coli usually do not produce any clinical symptoms in the animals or birds acting as reservoirs. Other than broilers, ducks (MA et al., 2012), turkeys (RANDALL et al., 2011) and wild birds (GUENTHER et al., 2012) have so far been explored as reservoirs of beta lactamase-producing $E$. coli.

In India, 'kuroiler' birds were introduced in the early 1990s by a private farm for farmers, as a new opportunity for better production of eggs and meat. Kuroilers are a dual purpose (egg and meat type) breed of birds, with higher productivity than indigenous breeds. The birds are successfully reared in a backyard system because they can easily scavenge food like indigenous birds (AHUJA et al., 2008). In India, earlier studies conducted 
in healthy livestock, such as cattle, pigs and broilers, revealed the existence of ESBLproducing E. coli and Klebsiella pneumoniae (LALZAMPUIA et al., 2013; LALZAMPUIA et al., 2014; SAMANTA et al., 2015; SAMANTA et al., 2015a; KAR et al., 2015; MANDAKINI et al., 2015). The status of other domestic birds such as kuroilers as reservoirs of extendedspectrum cephalosporinase-producing E. coli is still unexplored.

The present study was undertaken to detect the occurrence of extended-spectrum cephalosporinase gene possessing-E. coli (ESBL and ampC beta lactamase producers) in healthy kuroiler birds reared in West Bengal, India. The study was also intended to reveal co-resistance patterns against other antibiotics and the clonal relationship of the isolates.

\section{Materials and methods}

A total of 80 cloacal swabs from kuroiler birds were collected randomly from different locations of the Darjeeling District, West Bengal, India (Table 1). Samples were collected from apparently healthy birds of both sexes, from 3 months to one year in age. The birds were reared by intensive, semi-intensive or backyard systems. Use of costly antimicrobials (e.g. cephalosporins) for both prevention and therapeutic purposes was not practiced by the farmers. Occasionally the birds, including the sampled birds, were treated with amoxicillin and tetracycline during an outbreak.

Table 1. Locations of sample collection in Darjeeling district, West Bengal, India

\begin{tabular}{|c|l|l|c|}
\hline \multirow{2}{*}{ District } & \multicolumn{1}{|c|}{ Block } & \multicolumn{1}{|c|}{ Village } & No. of samples collected \\
\hline \multirow{4}{*}{$\begin{array}{c}\text { Darjeeling, } \\
\text { West Bengal }\end{array}$} & Bijanbari & Rajbari & 28 \\
\cline { 2 - 4 } & Sukhia Pokhari & Mem Kaman Tea Estate & 26 \\
\cline { 2 - 4 } & Kurseong & Fatak & 14 \\
\cline { 2 - 4 } & Darjeeling & Singamari & 12 \\
\hline \multicolumn{2}{|c|}{ Total } & 80 \\
\hline
\end{tabular}

The cloacal swabs were collected by sterile cotton swab sticks (HiMedia, India) and kept in sterile peptone water (HiMedia, India) for transport. The samples were brought to the laboratory maintaining the cold chain, and were processed within 48 hours.

The cloacal swabs collected in peptone water were inoculated into MacConkey's agar (HiMedia, India) and incubated at $37{ }^{\circ} \mathrm{C}$ for overnight. The next day rose pink colonies were picked and transferred into EMB agar (HiMedia, India) and again incubated overnight at $37{ }^{\circ} \mathrm{C}$. The colonies were observed after incubation and a single colony was streaked into nutrient agar (HiMedia, India) slants for further morphological and biochemical confirmation (QUINN et al., 1994).

The morphologically and biochemically verified E. coli isolates were subjected to PCR for confirmation, as described by WANG et al. (1996). The positive control, 
supplied by the Department of Veterinary Microbiology, Central Agricultural University, Mizoram, India, and sterile distilled water as the negative control were included in the PCR. The amplified product was visualized by a gel documentation system (UVP, UK) after electrophoresis in $2 \%(\mathrm{~W} / \mathrm{V})$ agarose (SRL, India) gel containing ethidium bromide $(0.5 \mu \mathrm{g} / \mathrm{ml})$ (SRL, India) (SAMBROOK and RUSSEL, 2001).

All the E. coli isolates, including controls, were subjected to PCR for detection of $b l a_{C T X-M}, b l a_{T E M,}, b l a_{S H V}$ and $b l a_{C M Y-2}$ genes, using the primers and cycle conditions described earlier (CAO et al., 2002; WEILL et al., 2004; SMET et al., 2008). The positive control supplied by the Department of Veterinary Microbiology, Central Agricultural University, Mizoram, India, and sterile distilled water as the negative control were included in the PCR. The primers used for amplification of CTX-M, SHV and TEM in the study are specific for CTX-M-9, SHV-12 and TEM-1, respectively.

The molecular characterization of all the extended-spectrum cephalosporinase gene possessing E. coli isolates was performed by RAPD-PCR (LIM et al., 2009). All the images captured by the gel documentation system were analyzed using Doc-itLs image analysis software, as per the manufacturer's instruction (UVP, UK). By comparing the differences in the banding pattern, the phylogenetic relationships among the isolates were established. An unrooted phylogenetic tree was made using the neighbour joining method.

All the extended-spectrum cephalosporinase gene possessing $E$. coli isolates were sent for serogrouping to the National Salmonella and Escherichia Centre, Central Research Institute, Kasuli, HP, India.

All the extended-spectrum cephalosporinase gene possessing $E$. coli isolates were tested using amikacin $(30 \mu \mathrm{g})$, ampicillin/cloxacillin $(10 \mu \mathrm{g})$, amoxicillin/clavulanic acid $(20 / 10 \mu \mathrm{g})$, ceftriaxone $(30 \mu \mathrm{g})$, gentamicin $(10 \mu \mathrm{g})$, piperacillin $(30 \mu \mathrm{g})$, ampicillin/ sulbactum $(10 / 10 \mu \mathrm{g})$, enrofloxacin $(10 \mu \mathrm{g})$, imipenem-EDTA $(10 / 75 \mu \mathrm{g})$, tetracyclin $(30$ $\mu \mathrm{g}$ ), azithromycin $(15 \mu \mathrm{g})$, and co-trimoxazole ( $25 \mu \mathrm{g}$ ) discs (Himedia, India) to study the sensitivity pattern of the isolates by the disc diffusion method (CLSI, 2008). The minimum inhibitory concentration breakpoints were used to interpret the zone diameter for each antibiotic, as mentioned in the Clinical and Laboratory Standards Institute (CLSI) guidelines (CLSI, 2008). Discs with CLSI-recommended antibiotic concentrations were used. However, if not available, a disc (co-trimoxazole) with the concentrations provided by the manufacturer was used. The positive control supplied by the Department of Veterinary Microbiology, Central Agricultural University, Mizoram, India was included in the study.

The occurrence of different extended-spectrum cephalosporinase genes among the $E$. coli strains isolated from kuroilers was compared by chi- square test using SPSS software version 17.0 (SPSS Inc.). 


\section{Results}

In the present study, a total of 60 isolates were presumptively identified as $E$. coli from the 80 cloacal samples of kuroiler birds examined. All the presumptive $E$. coli isolates showed the characteristic pink coloured colony in MacConkey agar, metallic sheen in EMB agar and the isolates were gram negative rods. The isolates showed the standard results for the biochemical tests conducted such as catalase (+ve), oxidase (-ve), IndoleMethyl Red-Voges Proskauer-Citrate (++ - - ) and Urease (-ve). All the 60 presumptive $E$. coli isolates were positive for 16s rRNA with an amplified product size of $585 \mathrm{bp}$ in PCR.

Among the 60 E. coli isolates, $12(20 \%)$ isolates possessed one of the studied extended-spectrum cephalosporinase genes. Among the three bla genes studied, $b l a_{T E M}$ and $b l a_{S H V}$ were detected in $6(10 \%)$ and $12(20 \%) E$. coli isolates, respectively (Table 2). None of the $E$. coli isolates possessed $b l a_{C T X-M}$ and $b l a_{C M Y-2}$ (Table 2). The majority of the extended-spectrum cephalosporinase gene possessing E. coli belonged to UT and O126 serogroups (Table 2).

Table 2. Genotype of extended-spectrum cephalosporinase $E$. coli $(\mathrm{n}=12)$ isolated from faecal samples of kuroilers in West Bengal, India

\begin{tabular}{|c|c|c|c|c|c|c|}
\hline Sample No & $\begin{array}{c}\text { E. coli 16S } \\
\text { rRNA PCR }\end{array}$ & bla $_{\text {SHV }}$ & bla $_{\text {TEM }}$ & bla $_{\text {CTX-M }}$ & bla $_{\text {CMY-2 }}$ & Serogroup \\
\hline PEC2 & + & + & - & - & - & O126 \\
\hline PEC3 & + & + & + & - & - & O126 \\
\hline PEC4 & + & + & + & - & - & OR \\
\hline PEC5 & + & + & - & - & - & OUT \\
\hline PEC7 & + & + & - & - & - & OUT \\
\hline PEC8 & + & + & + & - & - & O126 \\
\hline PEC9 & + & + & + & - & - & O77 \\
\hline PEC10 & + & + & - & - & - & O83 \\
\hline PEC11 & + & + & + & - & - & OUT \\
\hline PEC12 & + & + & + & - & - & OUT \\
\hline PEC13 & + & + & - & - & - & OUT \\
\hline PEC14 & + & + & - & - & - & OUT \\
\hline & $\mathrm{n}=12$ & $\mathrm{n}=12$ & $\mathrm{n}=6$ & $\mathrm{n}=0$ & $\mathrm{n}=0$ & \\
\hline
\end{tabular}

All 12 extended-spectrum cephalosporinase gene possessing E. coli isolates were characterized by RAPD-PCR to determine the genetic diversity. All the isolates were typeable with the RAPD primer, and the amplified fragment size was detected in the range of $150 \mathrm{bp}$ to $2165 \mathrm{bp}$ (calculated by Doc-itLs image analysis software, UVP, UK).The phylogenetic analysis revealed the absence of serogroup specific cluster. The extended -spectrum cephalosporinase-gene possessing $E$. coli strains isolated from same localities 
( PEC8/PEC10, PEC9/PEC11/PEC12) were grouped in the same clusters. Moreover, $E$. coli strains with similar extended-spectrum cephalosporinase genes $\left(b l a_{S H V}\right.$ possessing PEC7, PEC10, PEC13) and (bla $a_{T E M}$ and $b l a_{S H V}$ gene possessing PEC3, PEC9, PEC11, PEC12) were also grouped in the same cluster in the dendogram (Fig. 1).
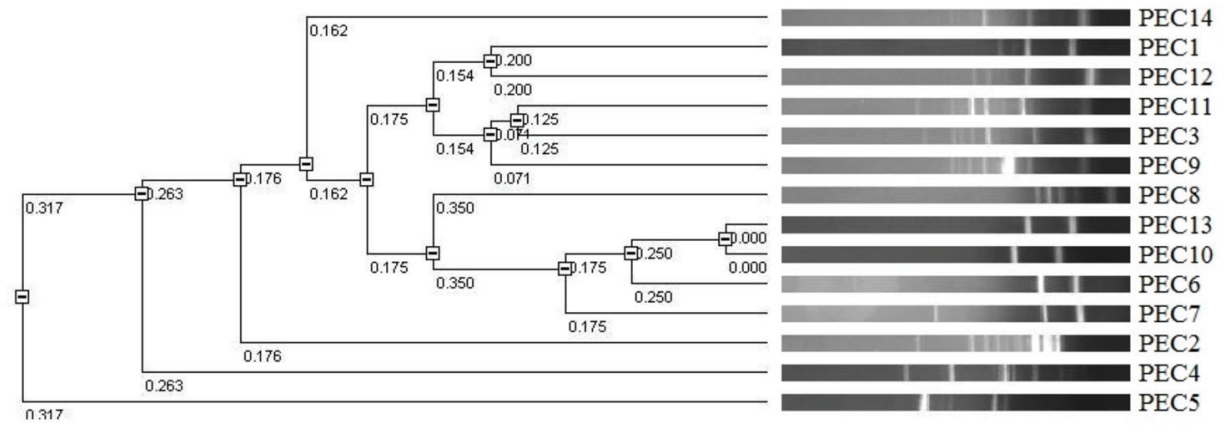

Fig. 1. Phylogenetic analysis of ESBL gene possessing E. coli strains isolated from healthy kuroilers in West Bengal (India). The neighbour-joining method was used to summarize the similarity of RAPD-PCR profiles of ESBL gene possessing E. coli strains in a dendogram.

Table 3. Phenotypical resistance pattern of extended-spectrum cephalosporinase E. coli $(\mathrm{n}=12)$ isolated from faecal samples of kuroilers in West Bengal, India

\begin{tabular}{|l|c|c|c|}
\hline Antibiotic $($ Conc. in $\mu \mathrm{g})$ & $\begin{array}{c}\text { No. of isolates } \\
\text { Sensitive }(\%)\end{array}$ & $\begin{array}{c}\text { No. of isolates } \\
\text { Intermediate (\%) }\end{array}$ & $\begin{array}{c}\text { No. of isolates } \\
\text { Resistance (\%) }\end{array}$ \\
\hline Amikacin $(30 \mu \mathrm{g})$ & $10(83.33)$ & $1(8.33)$ & $1(8.33)$ \\
\hline Amoxycillin/clavulanic acid $(20 / 10 \mu \mathrm{g})$ & $2(16.66)$ & $0(0)$ & $10(83.33)$ \\
\hline Ampicillin/Sulbactum $(10 / 10 \mu \mathrm{g})$ & $6(50.00)$ & $4(33.33)$ & $2(16.66)$ \\
\hline Azithromycin $(15 \mu \mathrm{g})$ & $3(25)$ & $4(33.33)$ & $5(41.66)$ \\
\hline Ceftriaxone $(30 \mu \mathrm{g})$ & $2(16.66)$ & $2(16.66)$ & $8(66.66)$ \\
\hline Co-Trimoxazole $(25 \mu \mathrm{g})$ & $1(8.33)$ & $0(0)$ & $11(91.66)$ \\
\hline Enrofloxacin $(10 \mu \mathrm{g})$ & $9(75.00)$ & $1(8.33)$ & $2(16.66)$ \\
\hline Gentamicin $(10 \mu \mathrm{g})$ & $12(100)$ & $0(0)$ & $0(0)$ \\
\hline Imipenem/EDTA $(10 / 75 \mu \mathrm{g})$ & $12(100)$ & $0(0)$ & $0(0)$ \\
\hline Piperacilin $(30 \mu \mathrm{g})$ & $2(16.66)$ & $0(0)$ & $10(83.33)$ \\
\hline Tetracycline $(30 \mu \mathrm{g})$ & $4(33.33)$ & $0(0)$ & $8(66.66)$ \\
\hline Ampicillin/Cloxacilin $(10 \mu \mathrm{g})$ & $0(0)$ & $0(0)$ & $12(100)$ \\
\hline
\end{tabular}

The resistance of extended-spectrum cephalosporinase gene possessing E. coli isolates was observed most frequently against ampicillin/cloxacillin (100\%), cotrimoxazole $(91.66 \%)$, amoxyclav $(83.33 \%)$, piperacillin $(83.33 \%)$, ceftriaxone $(66.66 \%)$, and tetracycline $(66.66 \%)$, and less frequently against amikacin $(8.33 \%)$, 
enrofloxacin (16.66\%), and ampicillin/sulbactum (16.66\%). No resistance was observed against imipenem/EDTA and gentamicin. All the isolates were resistant to three or more antimicrobial agents (Table 3).

\section{Discussion}

Escherichia coli harbouring any of the studied extended-spectrum cephalosporinase genes was detected in a few isolates $(12 / 60,20 \%)$ from West Bengal, India. Inclusion of susceptibility testing prior to PCR, for detection of resistance genes, might increase the number of isolates. Among the conventional and semi-automated systems for detection of ESBL-E. coli, the double disc test was reported earlier with the highest specificity and positive predictive value of all test methods (WIEGAND et al., 2007). This kind of occurrence study in kuroiler birds has apparently not been undertaken elsewhere in the world for comparison of findings. Prior studies in broilers in West Bengal revealed a higher occurrence rate (29.4\%) of ESBL-E. coli (SAMANTA et al., 2015a). However, in other states in India, such as in Odisha and in Mizoram, the occurrence of ESBL-E. coli in broilers was low (3.9\%-6.3\%) (LALZAMPUIA et al., 2014; KAR et al., 2015). Comparison of extended-spectrum cephalosporinase producing-E. coli occurrence with other studies is difficult due to differences in sample size, the methodology used in the laboratory, and geographical location.

Further, a few E. coli isolates (12/60, 20\%) from kuroiler birds possessed bla $_{S H V}$ in the present study, although there was no history of third generation cephalosporin intake by the birds. However, the present finding in kuroilers, without dietary intake of cephalosporins, is probably due to the use of other antibiotics. Resistance to other antibiotics (amoxicillin, tetracycline, chloramphenicol) is often linked with the generation of bla $a_{S H V}$ carrying betalactamse producing isolates, due to the linkage between the responsible genes located in the same mobile genetic element (REICH et al., 2013). Moreover, the majority of $E$. coli isolates from the broiler farm environment (rinse water), and the house fly (Musca domestica) isolates from the broiler farms, possessed bla ${ }_{S H V}$ (BLAAK et al., 2014, BLAAK et al., 2015). The contaminated environment may play a major role in transmission of $b l a_{S H V}$ gene possessing E. coli in the kuroiler birds studied. An earlier study in Japan revealed that contamination of the broiler house with ESBL-producing E. coli was a greater contributing factor to the occurrence than dietary intake of antibiotics (HIROI et al., 2012). Environmental compartments, such as soil enriched with contaminated manure, water, air and flies, were detected as vehicles for transmission of extended-spectrum betalactamase producing bacteria (BLAAK et al., 2015). Further, 6/60 (10\%) E. coli isolates were detected to possess $b l a_{T E M}$ along with $b l a_{S H V}$ in PCR. Similarly, $b l a_{T E M}$ and $b l a_{S H V}$ possessing $E$. coli isolates were detected from poultry meat samples in Italy (GHODOUSI et al., 2015). 
None of the E. coli isolates from kuroilers were positive for the presence of the $b l a_{C T X-M}$ gene by PCR, which is the most conspicuous finding in the present study. Among the ESBL enzymes, CTX-M was observed as the most prevalent type throughout the world specially in humans (CARATTOLI, 2013). Earlier studies in broilers around the world also identified that the majority of extended-spectrum beta-lactamase producing $E$. coli possessed $b l a_{C T X-M}$ due to widespread use of cefotaxime and ceftriaxone, or the high mobilization of the encoding gene (RANDALL et al., 2011; REICH et al., 2013; LALZAMPUIA et al., 2014). In the studied kuroilers, cefotaxime or third generation cephalosporins were not used for therapeutic or preventive purposes due to the high cost. Similarly, in our previous study in Rhode Island Red (RIR) backyard chickens, no ESBL-producing E. coli and Salmonella spp. were detected due to the lack of antibiotic use (SAMANTA et al., 2014; SAMANTA et al., 2014a). Moreover, it seems that the sulfonamide and trimethoprim groups of antimicrobials were also used neither in the studied kuroilers nor in the surrounding ecosystem, as the sulphonamide resistance genes present in class 1 integron may co-select bla $_{\text {CTX-M }}$ (SMET et al., 2008).

CMY-2 is considered to be the most prevalent ampC $\beta$-lactamase in E. coli and Salmonella isolated from food animals throughout the world, which led us to select the $b l a_{C M Y-2}$ gene in PCR (CORTES et al., 2010). None of the E. coli isolates from the kuroilers was positive for the $b l a_{C M Y-2}$ gene. The lack of therapeutic or preventive use of second or third generation cephalosporins in the studied kuroilers could explain the finding. However earlier, in a Swedish study in broilers, CMY-2 was detected in E. coli in the absence of cephalosporin use in the diet, and it was concluded that is was carried over from the parental stock (SVARM, 2010).

The majority of the extended-spectrum cephalosporinase gene possessing E. coli isolated from kuroilers belonged to an untypeable (UT) serogroup. ESBL-producing $E$. coli belonging to an untypeable serogroup was isolated earlier from piglets in India (MANDAKINI et al., 2015).

The phylogenetic analysis of extended-spectrum cephalosporinase-gene possessing E. coli isolates revealed a clonal relationship between the strains belonging to same place and ESBL-gene profile. This finding revealed the presence of some bacterial clones circulating among the kuroilers and the possibility of their spread into the human food chain (JOHNSON et al., 2007), or to other indigenous birds. Kuroilers kept in a backyard occasionally copulate with indigenous birds, which may act as an additional mode of transmission. ESBL-producing E. coli were recently detected in the reproductive tract of broiler breeding roosters, which suggests the possibility of the venereal route of transmission (MEZHOUD et al., 2015).

Multidrug resistance among the extended-spectrum cephalosporinase-gene possessing E. coli isolates in the present study was detected against co-trimoxazole, 
enrofloxacin, amikacin. The resistance against tetracycline among the isolates of the present study could be linked with possession of the $b l a_{S H V}$ gene (REICH et al., 2013). The susceptibility of the extended-spectrum beta-lactamase producing $E$. coli isolates to imipenem was also described in earlier study (GOYANES et al., 2007). Two extendedspectrum cephalosporinase-gene possessing $E$. coli isolates were found to be sensitive against ceftriaxone, which carried both bla $_{T E M-1}$ and $b l a_{S H V-12}$. It is difficult to presume which gene played the dominant role for these two isolates.

The present study revealed for the first time that kuroiler birds, with no high generation cephalosporin use, can act as a reservoir of extended-spectrum cephalosporinase-gene possessing E. coli. Detection of bla $a_{S H V}$ possessing E. coli in kuroilers should make consumers cautious about the use of kuroiler meat and eggs, because bla $a_{S H V}$ possessing isolates have been sporadically associated with human infections in the community (VOETS et al., 2013).

\section{Acknowledgements}

The authors express their sincere thanks to the honourable Vice Chancellor of West Bengal University of Animal and Fishery Sciences for the infrastructure. The work was carried out with the financial help of the Department of Biotechnology (DBT), Government of India.

\section{References}

AHUJA, V., M. DHAWAN, M. PUNJABI, L. MAARSE (2008): Poultry based livelihood of rural poor: Case of Kuroiler in West Bengal. F. South Asia Pro-Poor Livestock Policy Programme. New Delhi, India. 2008; http://www.sapplpp.org/doc-12-poultry-based-livelihood (accessed on 20.05.2016).

BLAAK, H., R. A. HAMIDJAJA, A. H. VAN HOEK, L. DE HEER, A. M. DE RODA HUSMAN, F. M. SCHETS (2014): Detection of extended-spectrum beta-lactamase (ESBL)-producing Escherichia coli on flies at poultry farms. Appl. Environ. Microbiol. 80, 239-246.

BLAAK, H., A. H. VAN HOEK, R. A. HAMIDJAJA, R. Q. VAN DER PLAATS, L. KERKHOFDE HEER, A. M. DE RODA HUSMAN, F. M. SCHETS (2015): Distribution, numbers, and diversity of ESBL-Producing E. coli in the poultry farm environment. PLoS One 10, e0135402.

CAO, V., T. LAMBERT, D. Q. NHU, H. K. LOAN, N. K. HOANG, G. ARLET, P. COURVALIN (2002): Distribution of extended-spectrum $\beta$-lactamases in clinical isolates of Enterobacteriaceae in Vietnam. Antimicrob. Agents Chemother. 46, 3739-3743.

CARATTOLI, A (2013): Plasmids and the spread of resistance. Int. J. Med. Microbiol. 303, 298304.

CLINICAL AND LABORATORY STANDARDS INSTITUTE (CLSI) (2008): Performance standards for antimicrobial susceptibility tasting; 18th informational supplement. M100-S18. Wayne, PA: Clinical and Laboratory Standards Institute. 
P. Ghosh et al.: Extended-spectrum cephalosporinase possessing E. coli in kuroilers

CORTES, P., V. BLANC, A. MORA, G. DAHBI, J. E. BLANCO, M. BLANCO, C. LOPEZ, A. ANDREU, F. NAVARRO, M. P. ALONSO, G. BOU, J. BLANCO, M. LLAGOSTERA (2010): Isolation and characterization of potentially pathogenic antimicrobial-resistant Escherichia coli strains from chicken and pig farms in Spain. Appl. Environ. Microbiol. 76, 2799-2805.

DE KRAKER, M. E. A., P. G. DAVEY, H. GRUNDMANN (2011): Mortality and hospital stay associated with resistant Staphylococcus aureus and Escherichia coli bacteremia: estimating the burden of antibiotic resistance in Europe. PLoS Med. 8, e1001104.

EFSA PANEL ON BIOLOGICAL HAZARDS (2011): Scientific opinion on the public health risks of bacterial strains producing extended-spectrum $\beta$-lactamases and/or AmpC $\beta$-lactamases in food and food-producing animals. EFSA J. 9, 2322.

GHODOUSI, A., C. BONURA, A. M. DI NOTO, C. MAMMINA (2015): Extended-spectrum B-lactamase, AmpC-Producing, and fluoroquinolone-resistant Escherichia coli in retail broiler chicken meat, Italy. Foodborne Pathog. Dis. 12, 619-25.

GOYANES, M. J., E. CERCENADO, R. INSA, A. MORENTE, L. ALCALÁ, E. BOUZA (2007): High rates of antimicrobial co-resistance among Enterobacteriaceae: comparative analysis between clinical isolates resistant and susceptible to third-generation cephalosporins. Rev. Esp. Quimioter. 20, 216-221.

GUENTHER, S., C. EWERS, L. H. WIELER (2012): Extended-spectrum beta-lactamases producing E. coli in wildlife, yet another form of environmental pollution? Analyzing possible intersections in the resistome among human, animal and environment matrices. 103.

HIROI, M., F. YAMAZAKI, T. HARADA, N. TAKAHASHI, N. IIDA, Y. NODA, M. YAGI, T. NISHIO, T. KANDA, F. KAWAMORI, K. SUGIYAMA (2012): Prevalence of extendedspectrum $\beta$-lactamase-producing Escherichia coli and Klebsiella pneumoniae in foodproducing animals. J. Vet. Med. Sci. 74, 189-195.

JOHNSON, J. R., M. R. SANNES, C. CROY, B. JOHNSTON, C. CLABOTS, M. A. KUSKOWSKI, J. BENDER, K. E. SMITH, P. L. WINOKUR, E. A. BELONGIA (2007): Antimicrobial drugresistant Escherichia coli from humans and poultry products, Minnesota and Wisconsin, 20022004. Emerg. Infect. Dis. 13, 838.

KAR, D., S. BANDYOPADHYAY, D. BHATTACHARYA, I. SAMANTA, A. MAHANTI, P. K. NANDA, B. MONDAL, P. DANDAPAT, A. K. DAS, T. K. DUTTA, S. BANDYOPADHYAY, R. K. SINGH (2015): Molecular and phylogenetic characterization of multidrug resistant extended-spectrum beta-lactamase producing Escherichia coli isolated from poultry and cattle in Odisha, India. Infect. Genet. Evol. 29, 82-90.

KLUYTMANS, J. A., I. T. OVERDEVEST, I. WILLEMSEN, M. F. KLUYTMANSVAN DEN BERGH, K. VAN DER ZWALUW, M. HECK, M. RIJNSBURGER, C. M. VANDENBROUCKE-GRAULS, P. H. SAVELKOUL, B. D. JOHNSTON, D. GORDON (2013): Extended-spectrum $\beta$-lactamase-producing Escherichia coli from retail chicken meat and humans: comparison of strains, plasmids, resistance genes, and virulence factors. Clin. Infect. Dis. 56, 478-487.

LALZAMPUIA, H., T. K. DUTTA, I. WARJRI, R. CHANDRA (2013): PCr-based detection of extended-spectrum b-lactamases (blaCTX-M-1 and blaTEM) in Escherichia coli, Salmonella 
P. Ghosh et al.: Extended-spectrum cephalosporinase possessing E. coli in kuroilers

spp. and Klebsiella pneumoniae isolated from pigs in North Eastern India (Mizoram). Indian J. Microbiol. 53, 291-296.

LALZAMPUIA, H., T. K. DUTTA, I. WARJRI, R. CHANDRA (2014): Detection of extendedspectrum $\beta$-lactamases (blaCTX-M-1 and blaTEM) in Escherichia coli, Salmonella spp., and Klebsiella pneumoniae isolated from poultry in North Eastern India. Vet. World 7, 1026-1031.

LIM, K. T., R. YASIN, C. C.YEO, S. PUTHUCHEARY, K. L. THONG (2009): Characterization of multidrug resistant ESBL-producing Escherichia coli isolates from hospitals in Malaysia. J. Biomed. Biotechnol. Vol. 2009, Article ID 165637.

DOI: $10.1155 / 2009 / 165637$

MA, J., J. H. LIU, L. LV, Z. ZONG, Y. SUN, H. ZHENG, Z. CHEN, Z. L. ZENG (2012): Characterization of extended-spectrum $\beta$-lactamase genes foundamong Escherichia coli isolates from duck and environmental samples obtained on a duck farm. Appl. Environ. Microbiol. 78, 3668-3673.

MANDAKINI, R., T. K. DUTTA, S. CHINGTHAM, P. ROYCHOUDHURY, I. SAMANTA, S. N. JOARDAR, A. R. PACHAUAU, R. CHANDRA (2015): ESBL-producing Shiga-toxigenic $E$. coli (STEC) associated with piglet diarrhoea in India. Trop. Anim. Hlth. Prod. 47, 377-381.

MARCHAIM, D., T. GOTTESMAN, O. SCHWARTZ, M. KOREM, Y. MAOR, G. RAHAV, R. KARPLUS, T. LAZAOVITCH, E. BRAUN, H. SPRECHER, T. LACHISH, Y. WIENERWELL, D. ALON, M. CHOWERS, P. CIOBOTARO, R. BARENSTEIN, A. PAZ, I. POTASMAN, M. GILADI, V. SCHECHNER, M. J. SCHWABER, S. KLARFELD-LIDJI, Y. CARMELI (2010): National multicenter study of predictors and outcomes of bacteremia upon hospital admission caused by Enterobacteriaceae producing extended-spectrum betalactamases. Antimicrob. Agents Chemother. 54, 5099-6104.

MEZHOUD, H., F. BOYEN, L. H. TOUAZI, A. GARMYN, N. MOULA, A. SMET, F. HAESBROUCK, A. MARTEL, M. IGUER-OUADA, A. TOUATI (2015): Extended -spectrum $\beta$-lactamase producing Escherichia coli in broiler breeding roosters: Presence in the reproductive tract and effect on sperm motility. Anim. Reprod. Sci.159, 205-211.

PACHOLEWICZ, E., A. LIAKOPOULOS, A. SWART, B. GORTEMAKER, C. DIERIKX, A. HAVELAAR, H. SCHMITT (2015): Reduction of extended-spectrum- $\beta$-lactamase- and AmpC- $\beta$-lactamase-producing Escherichia coli through processing in two broiler chicken slaughterhouses. Int. J. Food. Microbiol. 215, 57-63.

RANDALL, L. P., C. ClOUTING, R. A. HORTON, N. G. COLDHAM, G. WU, F. A. CLIFTONHADLEY, R. H. DAVIES, C. J. TEALE (2011): Prevalence of Escherichia coli carrying extended-spectrum $\beta$-lactamases (CTX-Mand TEM-52) from broiler chickens and turkeys in Great Britainbetween 2006 and 2009. J. Antimicrob. Chemother. 66, 86-95.

REICH, F., V. ATANASSOVA, G. KLEIN (2013): Extended-spectrum ß-Lactamase and AmpCproducing Enterobacteria in healthy broiler chickens, Germany. Emerg. Infect. Dis. 19, 12531259.

SAMANTA, I., S. N. JOARDAR, P. K. DAS, P. DAS, T. K. SAR, T. K. DUTTA, S. BANDYOPADHYAY, S. BATABYAL, D. P. ISORE (2014): Virulence repertoire, 
P. Ghosh et al.: Extended-spectrum cephalosporinase possessing E. coli in kuroilers

characterization, and antibiotic resistance pattern analysis of Escherichia coli isolated from backyard layers and their environment in India. Avian Dis. 58, 39-45.

SAMANTA, I., S. N. JOARDAR, P. K. DAS, T. K. SAR, S. BANDYOPADHYAY, T. K. DUTTA, U. SARKAR (2014a): Prevalence and antibiotic resistance profiles of Salmonella serotypes isolated from backyard poultry flocks in West Bengal, India. J. Appl. Poult. Res. 23, 536-545.

SAMANTA, I., S. N. JOARDAR, A. MAHANTI, S. BANDYOPADHYAY, T. K. SAR, T. K. DUTTA (2015): Approaches to characterize extended spectrum beta-lactamase / betalactamase producing Escherichia coli in healthy organized vis-a-vis backyard farmed pigs in India. Infect. Genet. Evol. 36, 224-230.

SAMANTA, I., S. N. JOARDAR, P. K. DAS, T. K. SAR (2015a): Comparative possession of shiga toxin, intimin, enterohaemolysin and major extended spectrum beta lactamase genes in $E$. coli isolated from backyard and farmed poultry in West Bengal, India. Iranian J. Vet. Res. 16, 90-93.

SAMBROOK, J., D. W. RUSSEL (2001): Molecular Cloning-A Laboratory Manual. Cold Spring Harbour, New York.

SMET, A., A. MARTEL, D. PERSOONS, J. DEWUlF, M. HEYNDRICKX, B. CATRY, L. HERMAN, F. HAESEBROUCK, P. BUTAYE (2008): Diversity of extended-spectrum betalactamases and class $\mathrm{C}$ beta-lactamases among cloacal Escherichia coli Isolates in Belgian broiler farms. Antimicrob. Agents Chemother. 52, 1238-1243.

SVARM (2010): Swedish Veterinary Antimicrobial Resistance Monitoring. The National Veterinary Institute (SVA), Uppsala, Sweden.

QUINN, P. J., M. E. CARTER, B. MARKEY, G. R. CARTER (1994): Clinical Veterinary Microbiology. Wolfe Publishing, London.

VOETS, G. M., A. C. FLUIT, J. SCHARRINGA, C. SCHAPENDONK, T. VAN DEN MUNCKHOF, M. A. LEVERSTEIN-VAN HALL, J. C. STUART (2013): Identical plasmid AmpC $\beta$-lactamase genes and plasmid types in E. coli isolates from patients and poultry meat in the Netherlands. Int. J. Food Microbiol. 167, 359-362.

WANG, R. F., W. W. CAO, C. E. CERNIGLIA (1996): PCR detection and quantitation of predominant anaerobic bacteria in human and animal faecal samples. Appl. Environ. Microbiol. $62,1242-1247$.

WEILL, F., R. LAILLER, K. PRAUD, A. KE'ROUANTON, L. FABRE, A. BRISABOIS, P. A. D. GRIMONT, A. CLOECKAERT (2004): Emergence of extended-spectrum- $\beta$-lactamase (CTXm-9)-producing multiresistant strains of Salmonella enterica Serotype Virchow in poultry and humans in France. J. Clin. Microbiol. 42, 5767-5773.

WIEGAND, I., H. K. GEISS, D. MACK, E. STÜRENBURG, H. SEIFERT (2007): Detection of extended-spectrum beta-lactamases among Enterobacteriaceae by use of semiautomated microbiology systems and manual detection procedures. J. Clin. Microbiol. 45, 1167-1174.

Received: 19 July 2016

Accepted: 21 May 2017 
GHOSH, P., A. MAHANTI, I. SAMANTA, S. N. JOARDAR, K. BATABYAL, S. DEY, S. TARAPHDER, D. P. ISORE: Izolati $E$. coli koji proizvode cefalosporinaze proširenog spektra izdvojeni iz kokoši pasmine kuroiler. Vet. arhiv 87, 745-757, 2017.

SAŽETAK

Istraživanje je poduzeto da se odredi incidencija bakterije $E$. coli koja posjeduje gene za cefalosporinaze proširenog spektra, a istodobno je rezistentna na druge antimikrobne tvari, te klonski odnos izolata u zdravih kokoši pasmine kuroiler. Ukupno je bilo nasumce prikupljeno 80 obrisaka kloake spomenute pasmine u Zapadnom Bengalu u Indiji. Skupe antimikrobne tvari (cefalosporini) nisu bile rabljene za liječenje. Izolati $E$. coli bili su identificirani standardnim biokemijskim testovima i 16SrRNA-PCR-om. Svi izolati bili su lančanom reakcijom polimerazom (PCR) pretraženi na prisutnost gena $b l a_{C T X-M}, b l a_{T E M,}, b l a_{S H V}$ i $b l a_{C M Y-2}$. Filogenetska srodnost izolata bila je određena RAPD-om. Otpornost svih izolata bila je fenotipski pretražena i na druge antibiotike. Ukupno je izdvojeno 60 izolata E. coli iz 80 kuroiler kokoši. Od toga je u 12 (20 \%) bio dokazan jedan od istraživanih gena za cefalosporinaze proširenog spektra. Među istraživanim genima, $b l a_{T E M}$ je bio dokazan u $6(10 \%)$ izolata, a $b l a_{S H V}$ u $12(20 \%)$ izolata E. coli. Nijedan od izolata nije posjedovao bla $_{C T X-M}$ i bla $a_{C M Y-2}$ Filogenetskom analizom ustanovljeno je da su izolati iz istih lokaliteta sa sličnim genetičkim profilom bili grupirani u istu skupinu. Posjedovanje gena za cefalosporinaze proširenog spektra bilo je najčešće dokazano za antibiotike ampicilin/kloksacilin, kotrimoksazol, amoksiklav, piperacilin, ceftriakson i tetraciklin. Perad pasmine kuroiler kojoj nikad nisu davani cefalosporini može biti rezervoar E. coli koja ima gene za cefalosporinaze proširenog spektra. To je prvo sustavno istraživanje u pasmine kuroiler od značenja za svjesnost konzumenata o mogućnosti prijenosa bakterije $E$. coli otporne na antimikrobne tvari.

Ključne riječi: $E$. coli, cefalosporinaze proširenog spektra, Indija, kuroiler 
